4-ORIGINALARTICLE

\title{
Effects of alpha-tocopherol on bacterial translocation and lipid peroxidation in rats with intestinal obstruction ${ }^{1}$
}

\author{
Alberto Schanaider ${ }^{2}$ \\ Leonaldson dos Santos Castro ${ }^{3}$ \\ Kalil Madi ${ }^{4}$
}

\begin{abstract}
Schanaider A, Castro LS, Madi K. Effects of alpha-tocopherol on bacterial translocation and lipid peroxidation in rats with intestinal obstruction. Acta Cir Bras [serial online] 2003 Jul-Aug;18(4). Available from URl: http://www.scielo.br/acb.
\end{abstract}

\begin{abstract}
Purpose: Investigate if alpha-tocopherol has a protective effect on intestinal mucosa after obstruction and to evaluate the potential relations between lipid peroxidation and bacterial translocation. Methods: Ten rats were submitted to a sham laparotomy and six served as control group. A small bowel obstruction was done in sixteen animals and among them eight were pretreated with alpha-tocopherol. Forty-eight hours later, mesenteric lymph node, spleen, liver and blood cultures and also samples from ileal mucosal were obtained, Thiobarbituric acid reactive substances (TBARS) levels were determined and intestinal histological assessment was performed. Results: Bacterial translocation was significantly increased in the obstructed rats compared with the control, sham and antioxidant pretreated groups $(\mathrm{p}<0,05)$. TBARS $(\mathrm{nmol} / 100 \mathrm{mg})$ in untreated obstructed rats increased from 49,0 $\pm 13,3$ in control group to $128,8 \pm 40$ after 48 hours of intestinal obstruction and achieved 72,3 $\pm 24,6$ in alpha-tocopherol group $(\mathrm{p}<0,05)$. Bacterial adherence to the intestinal epithelial cells surface and mucosal necrosis were significantly increased in the obstructed compared with nonobstructed rats. Conclusion: Alpha-tocopherol reduce the deleterious effects of the TBARS over the intestinal mucosal suggesting that in such circumstances there might be an association between bacterial translocation and lipid peroxidation after an intestinal occlusion.
\end{abstract}

KEY WORDS - Free radicals. Bacterial translocation. Lipid peroxidation.

\section{Introduction}

Under normal circumstances intestinal mucosa provides an efficient barrier against luminal bacteria and endotoxins. ${ }^{1}$ A number of diseases including intestinal obstruction induce bacterial translocation in humans and animals, leading to the risk of postoperative bacteremia or even septic complications. ${ }^{2,3}$ In fact a mechanical obstruction evokes an inflammatory response that causes intestinal edema with polymorphonuclear leukocytes accumulation and some degree of stasis in microcirculatory blood flow of the bowel wall. ${ }^{4}$ It is well known that leukocytes are a potential source of oxygen radical formation. ${ }^{2}$ Once these radicals are produced, begins a destructive chain reaction in the intracellular and extracellular spaces, also stimulating the process of lipid peroxidation in biological membranes. Furthermore the overproduction of reactive oxygen intermediates overwhelms the endogenous defense system.

1. Trabalho realizado no Departamento de Cirurgia da Faculdade de Medicina da Universidade Federal do Rio de Janeiro - UFRJ.

2. Professor Adjunto e Doutor do Departamento de Cirurgia da Faculdade de Medicina da UFRJ. Livre Docente da UNI-RIO.

3. Doutor pelo Departamento de Cirurgia da Faculdade de Medicina da UFRJ.

4. Professor Titular do Departamento de Patologia da Faculdade de Medicina da UFRJ. 
There are several potential reasons to explain the bacterial translocation but one strong possibility is the role of the respiratory burst from activated neutrophils. ${ }^{5}$ The following experiment attempts to test this hypothesis by evaluating the effect of the alphatocopherol, a lipid peroxid scavenger, on reducing the free radical-mediated damage of the intestinal cells.

\section{Methods}

Thirty two male Am-1-Tor rats, weighting 215 to $320 \mathrm{~g}$, housed under standard conditions were included for study. These rats were maintained in accordance with the recommendations of the National Institutes of Health publication "Guide for the Care and Use of Laboratory Animals" and the experiment were previously approved by the Institutional Board for Research at the Federal University of Rio de Janeiro. They were fasted for 12 hours before surgery and anesthetized with intraperitoneal $3 \%$ pentobarbital (30 $\mathrm{mg} / \mathrm{kg}$ ). The animals were randomly distributed into four groups. Group I $(n=6)$ was used as control. In group II (sham), ten rats underwent only a laparotomy. During 48 hours, the distal ileum of the remainder sixteen animals (groups III and IV) was completely occluded. It was done by means of a 3-0 silk string, double tied, $1 \mathrm{~cm}$ above the ileocecal valve, taking care not to interfere with the ileum blood supply. Eight rats (Group IV) were pretreated with intramuscular alphatocopherol (vitamin E), $500 \mathrm{mg} / \mathrm{kg}$ (Sigma Chemical Corp., St Louis, MO), on days 7 and 3 before the intestinal obstruction and at the day of operation. At the second laparotomy a careful inspection was achieved. Then the animals were put inside a laminar flow hood, and after applying aseptic procedures with sterile surgical materials, mesenteric lymph nodes, spleen, liver and a blood sample $(1 \mathrm{~mL})$ were obtained for quantitative and qualitative bacteriological analysis. A distal segment of the ileum $(6 \mathrm{~cm})$ was excised and immediately divided in three parts: one for culture study, another for TBARS level measurement and the last one for histologic assessment.

\section{Microbiologic study for testing bacterial translocation}

All visceral samples were weighted and tested. Using sterile technique, as described previously, each organ specimen (lymph node, liver, spleen and intestine) was homogenized with $0,5 \mathrm{~mL}$ of BHI (brain-heart infusion) with glass/Teflon homogenizer and aliquots $(0,2 \mathrm{~mL})$ were obtained. Serial dilution (from $10^{-1}$ to $10^{-9}$ ) in phosphate buffered saline (PBS), at $\mathrm{pH} 7.4$, were plated onto blood agar and MacConkey agar plates. All plates were incubated for 24 and 48 hours at $37^{\circ} \mathrm{C}$. All specimen evaluation were carried out in duplicate. Based on the weight of the tissue samples and the dilution used, total bacterial population levels in the organs removed were expressed as logarithmic colony-forming units/g (log CFU/g). After incubation the plates were then examined and gram-negative enteric bacilli and gram-positive cocci were identified by using standard microbiologic procedures. API 20E system (Mériux, Marcy-L'Etoile, France) was used for enterobacteriaceae identification. ${ }^{6}$

Bacterial growth in the blood samples, incubated for up to six days, was detected on a Bactec 9240 machine (Becton Dickinson, Maryland).

\section{Biochemical assay}

TBARS in distal ileum mucosa were measured as described by the Yagi method. ${ }^{7}$ Aliquots $(0.2 \mathrm{~mL})$ of homogenized ileum were mixed with sodium dodecyl sulfate $(0.2 \mathrm{~mL}, 8.1 \%)$, acetic acid $(1.5 \mathrm{~mL}, 20 \%)$, aqueous thiobarbituric acid ( $1.5 \mathrm{~mL}, 0.8 \%)$, at $\mathrm{pH} 3.5$ adjusted with sodium hydroxide, and distilled water was added to the total volume of $4.0 \mathrm{~mL}$. The mixture was incubated at $95^{\circ} \mathrm{C}$, for 60 minutes and cooled in water stream. After that $1.0 \mathrm{~mL}$ of distilled water and $5.0 \mathrm{~mL}$ of n-butanol/pyridine solution (15:1) were also added. This mixture was vigorously mixed (with a vortex machine) and centrifuged at $4000 \mathrm{rpm}$, for 10 minutes. Then the absorbency of the supernatant extracted was measured at $532 \mathrm{~nm}$ in a GBC 920 spectrophotometer. Tetramethoxypropane was used to standardization and the results were determined by the method of Lowry et al. ${ }^{8}$

\section{Histologic and morphometric investigation}

Tissue samples of distal ileum were fixed in FAM solution (a mixture of formaldehyde 10\%, acetic acid $10 \%$ and methanol $80 \%$ ), embedded in paraffin, cut $(5 \mathrm{~mm}$.) parallel to the villus-crypt axis, stained with hematoxylin and eosin and examined by light microscopy.

Each specimen in this study was examined in a blinded fashion by a single pathologist (KM). The following abnormalities - bacterial adherence to epithelium, to lamina propria or to inner layers of small intestine were scored as absent (grade 0), light (1), mild (2) or severe (3). Villus and crypt epithelial cell inflammation and necrosis were graded as follows: 0 , no visible injury; $1+$, epithelium occasionally affected; $2+$, majority of crypts and villi affected; $3+$ intense and widespread necrosis of the crypts and villi. The villus/crypt height ratio was graduated as $3: 1,2: 1,1: 1$; 
respectively to normal, slightly or greatly altered patterns. At least five measurements were made on each fragment.

\section{Statistical evaluation}

For multiple comparisons of the biochemical data (TBARS) and bacterial population the Kruskal-Wallis test was performed. Translocation incidences and histologic data were evaluated by chi square analysis with the Yates correction. Differences were considered significant at $\mathrm{p}<0.05$.

\section{Results}

None of the rats died during this experiment. At the second laparotomy, it was observed in groups III and IV an intestinal distention with slight congestion. Bowel perforation or infarction, and even peritonitis were not found.

The bacterial population levels were 100 to 1000 fold higher in the groups with intestinal obstruction. (Table 1). E. coli was the single most common organism recognized in all groups. (65\% in groups I and II, and 90,9\% in groups III and IV).

TABLE 1 - Bacterial population level in the ileum

\begin{tabular}{cc}
\hline Group & Ileal population levels $(\log \mathbf{C F U / g})$ \\
\hline I $(\mathrm{n}=6)$ & $3.9 \pm 1.8 \times 10^{6}$ \\
II $(\mathrm{n}=10)$ & $4.5 \pm 1.9 \times 10^{6}$ \\
III $(\mathrm{n}=8)$ & $3.1 \pm 3.3 \times 10^{9 *}$ \\
IV $(\mathrm{n}=8)$ & $3.1 \pm 1.8 \times 10^{9 *}$ \\
\hline
\end{tabular}

$\mathrm{p}<0.01$ compared with groups I and II.

Values are means \pm SD.

Bacterial translocation was studied in four organs of each rat. Thus, in each group it was established an index to evaluate this translocation $(\mathrm{BTI}=$ numbers of organs with at least one positive culture/number of organs studied). There was a significant difference between the groups $\left(\mathrm{c}^{2}=27.36, \mathrm{p}<0.001\right)$. When the values of group III were compared with those of groups
I, II and IV, chi-squared test showed significant differences (Table 2; $\mathrm{p}<0.05$ ). Considering separately each organ which showed bacterial translocation, it was seen statistically significant difference only when lymph nodes in group IV were compared with those of the other groups $\left(c^{2}=13.10, p=0.03\right)$.

TABLE 2 - Bacterial translocation index (BTI).

\begin{tabular}{ccc}
\hline Group & BTI & Percentage \\
\hline I & $1 / 24$ & 4.2 \\
II & $4 / 40$ & 10.0 \\
III & $17 / 32$ & 53.1 \\
IV & $7 / 32$ & 22.0 \\
\hline
\end{tabular}

$\mathrm{BTI}=$ number of organs with at least one positive culture /number of organs studied

The TBARS levels were examined by using analysis of variance and the results showed $\mathrm{H}=24,79$ with $\mathrm{p}<$ 0.001 . The highest TBARS levels were found in group III. (Table 3). Significant differences were detected between the values of groups I and II versus groups III and IV $(p<0.05)$. TBARS levels were also significantly elevated in group III when compared with the results of group IV $(\mathrm{p}<0.05)$.

TABLE 3 - TBARS levels on each group.

\begin{tabular}{ccc}
\hline Group & TBARS $(\mathbf{n m o l} / \mathbf{1 0 0 m g}$ protein) & p \\
\hline I $(\mathrm{n}=6)$ & $49.0 \pm 13.3$ & - \\
II $(\mathrm{n}=10)$ & $51.0 \pm 9.5$ & $\mathrm{I}=\mathrm{II}$ \\
III $(\mathrm{n}=8)$ & $128.8 \pm 40$ & $\mathrm{III}^{1} \mathrm{I}_{\text {and }} \mathrm{II}^{*}$ \\
IV $(\mathrm{n}=8)$ & $72.3 \pm 24.6$ & $\mathrm{IV}{ }^{1} \mathrm{III}^{*} ; \mathrm{IV}^{1} \mathrm{I}_{\text {and }} \mathrm{II}^{*}$ \\
\hline
\end{tabular}

* $\mathrm{p}<0.05$

Values are means \pm SD. 
In the groups I and II the villus/crypt height ratio was normal or slightly altered $(3: 1,2: 1)$. No bacterial adherence to epithelium occurred. Epithelial necrosis was seldom present (1+). On the other hand in group III it was observed that the epithelial cells of the upper two thirds of the villi were desquamated. In some areas almost whole epithelium had been sloughed off into the lumen only remaining in place the lamina propria. The majority of crypts and villi were affected and in most of the times necrosis was severe but without injury of the muscular layer (Figure 1). Bacterial adherence to the detached epithelium or to the lamina propria was severe and frequently seen (Figure 2). It was also noticed bacteria inside lymphatics of the submucosa (Figure 3). The villi were markedly shortened and crypt length was greater than in normal intestines with a villus/crypt height ratio ranging from 1:1 to $2: 1$ ( $p<0.05$ versus groups I, II and IV).

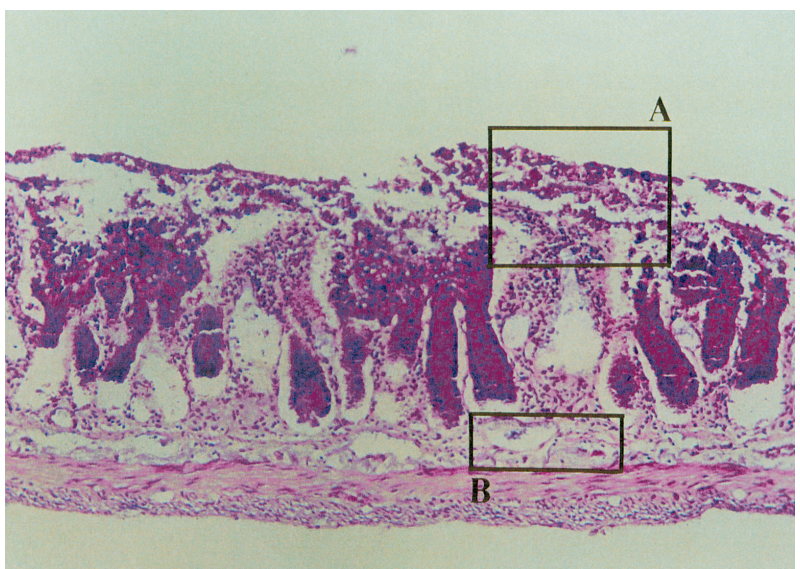

FIGURE 1 - Mucosal lesions of small bowel in obstructed animals without alpha - tocopherol. (HE, X100).

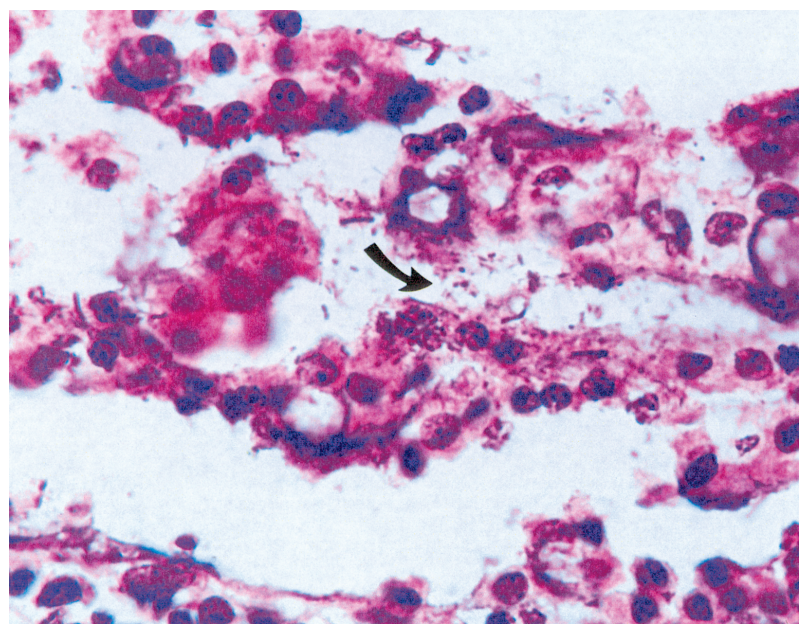

FIGURE 2 - Details (rectangle A of Figure 1) of epithelial lifting and bacterial invasion (see the arrow) of lamina propria (HE, $\mathrm{X} 1000)$.

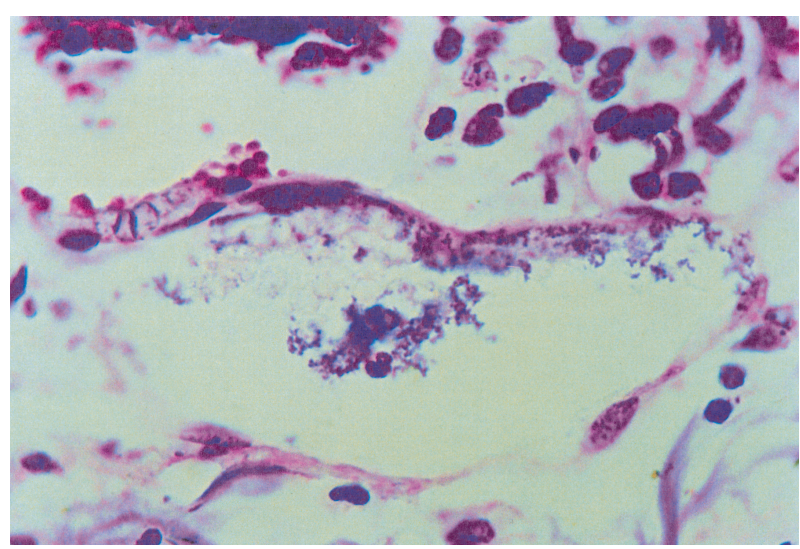

FIGURE 3 -The rectangle $B$ of figure 1, point to an area where it could be seen a lymphatic in the submucosa containing several coccus and bacilli. (HE, X1000).

Alpha-tocopherol pretreated animals (group IV) exhibited minimal injury with occasional edema of mucosa and submucosa with little signs of inflammatory infiltration of the lamina propria, sporadic epithelial lifting of the upper third of the villi and slightly reduction of villus/crypt height ratio (1:1) (Fig 4). Bacterial adherence was light. No bacterial translocation was seen in groups I and II. Only two animals of group IV showed a slight translocation to the submucosal layer. However six rats of group IV had remarkable translocation $(\mathrm{p}<0.05)$.

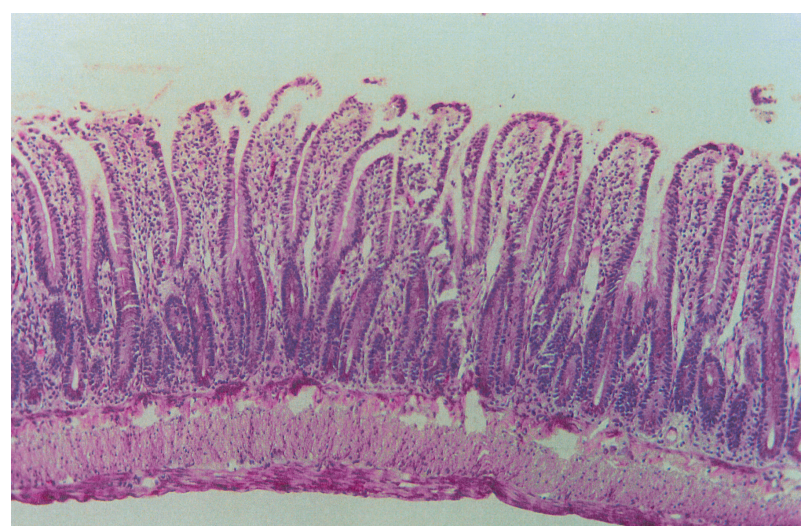

FIGURE 4 - Mucosal integrity with slight lesions, observed in alpha-tocopherol group. (HE, X100).

Statistical analysis by $c^{2}$ non-parametric test of tissue necrosis revealed significant difference when results of groups III were compared with those of the other groups $(\mathrm{p}<0.01)$.

\section{Discussion}

It is well known that small bowel obstruction promotes neutrophil activation and macrophages stimulation. Neutrophils contain an NADPH oxidase that reduces molecular oxygen to the superoxide radical 
$\left(\mathrm{O}_{2}-\right)$. This anion may then undergo further reduction to form hydrogen peroxide $\left(\mathrm{H}_{2} \mathrm{O}_{2}\right)$ and the hydroxyl radical $(\mathrm{OH} \bullet)$. Other reactive oxygen metabolites (hypochlorous acid and monochloramine) are also produced from the respiratory burst in activated neutrophils. All these highly reactive agents stimulate a self-propagating process of lipid peroxidation leading to damage of the biological membranes. ${ }^{9-11}$ The peroxidative process of degradation involves an initial step in which arachidonic acid, one of the most important polyunsaturated fatty acids $(\mathrm{RH})$ of cellular membranes, interacts with a reactive oxidizing radical $(\mathrm{X} \bullet)$. This results in the removal of a hydrogen atom to form a lipid radical $(\mathrm{R} \bullet)$ which rapidly reacts with molecular oxygen to generate a lipid peroxide free radical (ROO•). This radical can also converts into an endoperoxide radical. Finally another hydrogen atom is extracted from an adjacent lipid (RH) to form lipid hydroperoxide $(\mathrm{ROOH})$ and a second lipid radical $(\mathrm{R} \bullet)$ (Figure 5). Alternatively, the outcome may be the decomposition of lipid hydroperoxides and endoperoxides leading to the formation of malonaldehyde and malondialdehyde. ${ }^{9,10,12}$

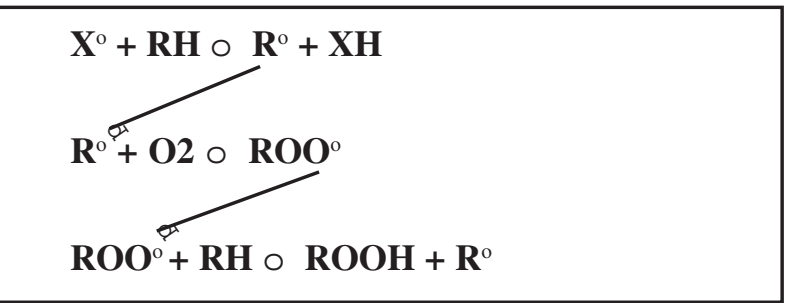

FIGURE 5 - Lipid peroxidation mechanism.

$\mathrm{X}^{\circ}=$ free radical $\mathrm{R}^{\circ}=$ lipid radical $; \mathrm{ROO}^{\circ}=$ lipid peroxide; $\mathrm{ROOH}=$ lipid hydroperoxide

Our data showed that when these products of lipid peroxidation were assayed in the distal ileum mucosa of untreated obstructed animals, high levels of TBARS were detected. These results suggested that free radicals and lipid peroxidation generated in bowel obstruction may be potential factors in intestinal cell membrane disruption and thus leading to gut barrier failure.

Histopathology showed remarkable mucosal morphologic changes in rats with intestinal obstruction without administration of alpha-tocopherol. Generally the lesions were characterized by massive edema of mucosa and submucosa with epithelial lifting, sometimes coupled with necrosis and complete villi denudation. It was also seen a considerable reduction in the height of the villi. These damages are quite similar to those reported by many authors after a transient ischemia, although having different pathogenesis. ${ }^{13,14}$ Both mechanisms are source of the same radical species but one is mediated by reperfusion and xanthine oxidase conversion and the other, as shown in the present study, is triggered by neutrophil action over biomembranes after an inflammatory insult. ${ }^{15}$

Bacterial overgrowth, bacterial adherence to mucosal surface and intestinal injury contribute to enhance bacterial translocation. ${ }^{16,17}$ We identified bacterial translocation to submucosa. Deitch reported bacterial translocation to mesenteric lymph nodes in patients with intestinal obstruction and in the absence of necrotic bowel. ${ }^{18}$ In our experiment one animal in the normal group and also ten percent of the rats who underwent just a laparotomy had translocation to mesenteric lymph nodes. This occurrence had already been described by Redan, but the explanation has remained unclear. ${ }^{19}$

In our microbiologic study $E$ coli was the most common isolated microorganism and it has consistently been reported in both animal and human studies. ${ }^{2}$

Several exogenous scavengers (for example: allopurinol, mannitol, dimethyl-sulfoxide and deferoxamine), have been used to prevent intestinal damage in consequence of oxygen-derived free radicals and lipid radicals actions. Administration of alpha-tocopherol (Vitamin E), a lipid soluble antioxidant, may prevent the lipid peroxidation over polyunsaturated fatty acid localized in cellular membranes. ${ }^{9}$ Our data were consistent with other authors who have found beneficial effect when animals were treated with alpha-tocopherol. ${ }^{20-22}$ Therefore if alpha-tocopherol may prevent the loss of biomembranes integrity and reduces the bacterial translocation, it is reasonable to suppose that both occurrences are linked at the same pathogenic process.

\section{Conclusion}

The presence of small bowel obstruction, peroxidative process seems to play an important role in bacterial translocation. Besides alpha-tocopherol may be useful to reduce tissue injury and bacterial translocation.

\section{References}

1. Brandtzaeg P, Halstensen TS, Kett K, Krajci P, Kvale D, Rognum TO, et al. Immunobiology and immunopathology of human gut mucosal: humoral immunity and intraepithelial lymphocytes. Gastroenterology 1989; 97:1562-84.

2. Sagar PM, MacFie J, Sedman P, May J, Mancey-Jones B, Johnstone D. Intestinal obstruction promotes gut translocation of bacteria. Dis Colon Rectum; 1995; 38:640-4.

3. Zhi-yong S, Yuan-lin D, Xiao-hong W. Bacterial translocation and multiple systemic organ failure in bowel ischemia and reperfusion. J Trauma 1992; 32:148-53.

4. Parks D, Bulkley GB, Granger N. Role of oxygen-derived free radicals in digestive tract diseases. Surgery 1983; 94:415-22.

5. Horton JW, Walker PB. Oxygen radicals, lipid peroxidation, and permeability changes after intestinal ischemia and reperfusion. J Appl Physiol. 1993; 74: 1515-20.

6. Smith PB, Tomfohrd KM, Rhoden DL, Balows A. API system: a multitube micromethod for identification of enterobacteriaceae. Appl Microbiol 1972; 24:449-52. 
7. Ohkawa H, Ohishi N, Yagi K. Assay for lipid peroxides in animal tissues by thiobarbituric acid reaction. Anal Biochem 1979; 95:351-8.

8. Lowry oH, Rosenbrough NJ, Farr Al, Randall RJ. Protein measurement with the folin phenol reagent. J Biol Chem 1951; 193:265-75.

9. Barber AA; Bernheim F. Lipid peroxidation: Its measurement, occurrence, and significance in animal tissues. Advances Geront Res 1967; 2:355-60.

10. Bertrand Y. Oxygen-free radicals and lipid peroxidation in adult respiratory distress syndrome. Intensive Care Med 1985; 11:56-60.

11. Van Der Vliet A; Blast A .Role of reactive oxygen species in intestinal diseases. Free Rad Biol Med 1992; 12:499-513.

12. Ward PA, Till GO, Hatherill JR, Annesley TM, Kunkel RG. Systemic complement activation, lung injury and products of lipid peroxidation. J Clin Invest 1985; 76: 517-27.

13. Hammerman C, Goldschmidt D, Caplan M, Kaplan M, Schimmel MS, Eidelman AI et al. Amelioration of ischemia reperfusion injury in rat intestine by pentoxifylline-mediated inhibition of xanthine oxidase. J Pediatr Gastroenterol Nutr 1999; 29:69-74.

14. Parks DA; Granger DN, Bulkley GB, Shah AK. Soybean trypsin inhibitor attenuates ischemic injury to feline small intestine. Gastroenterology 1985; 89:6-12.

15. Thompson A, Hemphill D, Jeejeebhoy KN. Oxidative stress and antioxidants in intestinal disease. Dig Dis 1998; 16:152-8.
Deitch EA. Simple intestinal obstruction causes bacterial translocation in man. Arch Surg 1989; 124:699-701.

16. Horgan AF, Stuart EM, O'Shaughnessy B, Cryan B, Kirwan WO. Bacterial translocation during peroperative colonic lavage of obstructed rat colon. Br J Surg 1994; 81:1796-8.

17. Katayama M, Xu D, Specian RD, Deitch EA. Role of bacterial adherence and the mucus barrier on bacterial translocation. Ann Surg 1997; 225:317-26.

18. Deitch EA. Simple intestinal obstruction causes bacterial translocation in man. Arch Surg 1989; 124:699-701.

19. Redan JA, Rush BF, Lysz TW, Smith S. Machiedo GW. Organ distribution of gut-derived bacteria caused by bowel manipulation or ischemia. Am J Surg 1990;159:85-90.

20. Reis E, Kama NA, Coskun T, Korkusuz P, Ors U, Aksoy M, et al. Effects of octreotide and a-tocopherol on bacterial translocation in experimental intestinal obstruction: a microbiological, light and electronmicorscopical study. Hepatogastroenterology 1997; 44:656-63.

21. Marubayashi S, Dohi K, Sugiro K. The protective effect of administered a-tocopherol against hepatic damage caused by ischemia-reperfusion or endotoxemia. Ann N Y Acad Sci 1989; 570:208-18.

22. Sato K, Niki E, Shimasaki H. Free radical mediated chain oxidation of low density lipoprotein and it's synergistic; inhibition by E and C. Arch Bioch Bioph 1990; 279:402-5.

Schanaider A, Castro LS, Madi K. Efeito do alfa-tocoferol sobre a translocação bacteriana e a peroxidação lipídica, em ratos com obstrução intestinal. Acta Cir Bras [serial online] 2003 JulAgo;18(4). Disponível em URL: http://www.scielo.br/acb.

RESUMO - Objetivo: Investigar se o alfa-tocopherol tem um efeito protetor na mucosa após uma obstrução intestinal e avaliar as relações potenciais entre a peroxidação lipidica e a translocação bacteriana. Métodos: Dez ratos foram submetidos a uma laparotomia (simulação) e seis outros foram utilizados como grupo controle. Empreendeu-se uma obstrução no intestino delgado de dezesseis animais e dentre eles, oito foram pré tratados com alfa-tocopherol. Quarenta-oito horas depois foram obtidas amostras de linfonodos mesentéricos, baço, fígado e culturas de sangue e da mucosa ileal. Os níveis das substâncias reativas do ácido tiobarbiturico (TBARS) foram determinados, assim como efetuada avaliação histológica intestinal. Resultados: A translocação bacteriana aumentou, significativamente, nos ratos obstruídos quando comparados aos dos grupos controle, simulação e pré tratados com antioxidante $(\mathrm{p}<0,05)$. O TBARS $(\mathrm{nmol} / 100 \mathrm{mg})$ em ratos com obstrução e sem tratamento aumentou de 49,0 \pm 13,3 no grupo de controle para 128,8 \pm 40, depois de 48 horas de obstrução intestinal e alcançou 72,3 \pm 24,6 no grupo tratado com o alfa-tocoferol $(\mathrm{p}<0,05)$. A aderência bacteriana a superfície das células do epitélio intestinal e a necrose da mucosa aumentaram, de modo significativo, nos ratos obstruídos, comparados aqueles sem a intervenção cirúrgica. Conclusão: O alfa-tocoferol reduz os efeitos deletérios do TBARS sobre a mucosa intestinal, circunstância esta que sugere a possibilidade da associação entre a translocação bacteriana e a peroxidação lipídica, após uma obstrução intestinal.

DESCRITORES - Radicais livres. Translocação bacteriana. Peroxidação lipídica.

Correspondence:

Conflict of interest: none

Alberto Schanaider

Rua Eurico Cruz, 33/603

22461-200 Rio de Janeiro - RJ

alberto@sr1.ufrj.br

Data do recebimento: 22/03/2003

Data da revisão: 02/04/2003

Data da aprovação: 12/04/2003 